\title{
Croatian Maritime Code Reform - Charter and Contract of Nautical Berth
}

\section{Reforma hrvatskog pomorskog zakonika - ugovor o najmu jahte i brodice te ugovor o nautičkom vezu}

\author{
Ante Vuković \\ Split \\ e-mail: antevukovic17@net.hr
}

\author{
DOI 10.17818/NM/2019/1.6 \\ UDK 347.79(088.4) \\ Review / Pregledni rad \\ Paper accepted / Rukopis primljen: 11. 7. 2018.
}

Summary

The aim of this paper is to analyse the Draft Act on the Amendments to the Maritime Code of the Republic of Croatia, focusing mainly on its chapters related to the yachts and small recreational boats charter, as well as contract of nautical berth and to compare them with the laws and practices in Italy, Spain and France.

\section{Sažetak}

Cilj je rada analizirati Nacrt prijedloga Zakona o izmjenama i dopunama Pomorskog zakonika Republike Hrvatske, u dijelu koji se tiče ugovora o najmu jahte i brodice te ugovora o nautičkom vezu, u usporedbi s pravom i praksom Italije, Španjolske $i$ Francuske.

\section{KEY WORDS}

charter

nautical berth

Croatian Maritime Code

comparative laws

nautical tourism

KLJUČNE RIJEČI

najam jahte i brodice

nautički vez

Pomorski zakonik Republike Hrvatske komparativna prava

nautički turizam

\section{INTRODUCTION / Uvod}

Nautical tourism is an extremely important industry for each country with access to the sea. According to the report released by the Croatian National Bureau of Statistics dated March 27, 2018, in 2017 there were 140 nautical ports on the seashore of the Republic of Croatia, including 70 marinas (13 of which were dry docks) and 70 nautical ports of other types. The total sea waters cover an area of 3711951 m2 with 17067 berths. The total revenue obtained from nautical port charges in 2017 amounted to 855 million Croatian kunas (approx. EUR 115 million). The revenue amounting to 598 million Croatian kunas (approx. EUR 80 million) was generated through mooring rental, accounting for $70.0 \%$ of the total revenue. In comparison to year 2016 , total revenue increased by $11.2 \%$, and the mooring rental revenue increased by $10.9 \%$. According to the type of vessels permanently moored, there were mostly sailboats which accounted for $51.0 \%$, followed by motorboats (45.6\%) and other vessels (3.4\%).

Such a dynamic industry requires a comprehensive legal framework as well. In order to increase legal certainty, the Government of the Republic of Croatia has introduced the Draft Bill to the Act on Amendments to the Maritime Code. The Act stipulates that the incoming contracts set out in the Croatian Maritime Code regulate the yacht and boat lease agreement, and the berthing agreement, with yachts and boats being leased and intended for recreation purposes, while berthing agreements do not apply to berths at other ports (i.e., sports ports). Will the set of new regulations related to the nautical tourism enable its growth which is as follows: a) smart (through development of knowledge and innovation), b) sustainable (based on a more eco-friendly and resource-efficient and competitive economy), and c) inclusive (oriented towards encouraging employment, as well as social and territorial cohesion)?

Therefore, the purpose of this research is to analyze the impact of The Draft Bill to the Act on Amendments to the Maritime Code to the nautical tourism. Accordingly, the aim of the research is to estimate the factors that contribute to the development of nautical tourism through the said Draft. The affirmatively set up research hypothesis says that a new treatment on the yacht and boat charter agreements, as well as nautical berth agreements, will ensure even faster growth of nautical tourism in Croatia, especially in terms of sustainable development.

This research paper is divided into six interrelated parts. The second part of the paper, following the introduction, provides a brief survey of the Croatian nautical ports and vessels in the ports. The third part of the paper, which is also the most extensive one, provides an update on the Draft Bill to the Act on Amendments to the Maritime Code. The fourth part of the paper provides a general description of the terms set out in the Law on Providing Services in Tourism. The fifth part of the paper refers to comparative law and practice in Italy, Spain, and France. The paper ends with a conclusion as the essence of research.

\section{GENERAL INFORMATION ON THE PORTS OF NAUTICAL TOURISM AND VESSELS IN THE PORTS/ Općenito o lukama nautičkog turizma i plovnim objektima u njima}

The term marina (the port for small boats) has been present in the history of the Croatian maritime law for more than 40 years now. The Croatian Maritime and Inland Water Domain, Ports and 
Docks Act of 1974 (OG 19/74, 24/74, 39/74, 39/75, 17/77, 18/81), marina represents a type of maritime domain used for special needs and purposes (special purpose ports) (Art. 42). I. Grabovac (1993) states that each "special purpose port is the so-called purpose-specific port, and the principle of equal treatment does not apply to its use". The Maritime Code of 1994 (OG 17/94) does not regulate the term seaport at all. The term is regulated by the Act on Amendments to the Maritime Code (OG 74/94) classifying the term "seaport coastline" in the maritime domain category (Art.1). This is why D. Bolanča (2003) calls the period of legal vacuum in determining the seaport as part of the maritime domain (March 22, 1994 - October 26, 1994) the "absurd situation". According to the Seaport Act of 1995 (OG 158/95), as well as the current Maritime Domain and Seaports Act of 2003 (OG 158/03, 100/04, 141/06, 38/09, 123/11, 56/16) nautical tourism ports are special-purpose ports. According to Art. 2, par. 1 of the Regulation on Classification and Categorization of Ports for Nautical Tourism (OG 72/08), a nautical tourism port is a commercial and functional unit in which a legal or natural person operates and provides nautical tourism services and other services related to the tourist consumption (commercial, catering and other services). The nautical tourism ports are classified into the following categories: 1) anchorage, 2) vessel storage facility, 3) dry dock, 4) marina.

The term yacht is mentioned for the first time in the Maritime and Inland Navigation Act of 1977 (Official Gazette of the former Socialist Federal Republic of Yugoslavia, 22/77). ${ }^{1}$ It is a watercraft used for non-commercial purposes for entertainment, sports or recreation (Art. 6, par. 21). The afore-mentioned Maritime Code of 1994 defines the terms such as ship, boat, yacht and foreign yachts (Art. 5). Ship, excluding warship, is a vessel intended for maritime navigation, the length of which is over $12 \mathrm{~m}$ and gross tonnage is over 15 , or it is authorized to carry more than 12 passengers. Boat is a vessel intended for maritime navigation which is not a ship; a yacht is a power vessel or a boat which is used for non-commercial purposes for entertainment, sports and recreation; a foreign yacht is a power vessel or boat of foreign nationality, used for non-commercial purposes for entertainment, sports and recreation, and which is regarded as such according to the regulations of a specific country as well. In the current Maritime Code of 2004 (OG 181/04, 76/07, $146 / 08,61 / 11,56 / 13,26 / 15$. - hereinafter referred to as: MC) the term ship has not changed its meaning compared to the previous Code. The Art. 5 of the MC provides definitions of the terms: boat, yacht and foreign yacht. Boat is a vessel intended for maritime navigation which is not a ship or yacht, the length of which is over $2.5 \mathrm{~m}$, of the total propulsion power over $5 \mathrm{~kW}$ (the term boat does not include the following: - vessels which belong to another vessel for the purpose of collecting, rescuing or the execution of work, - vessels intended exclusively for competition, - canoes, kayaks, gondolas and pedalos, sailboards and surfboards). Yacht is a vessel intended for sports and entertainment, regardless of whether it is used for personal use or for business use, the length of which is over $12 \mathrm{~m}$, and which is intended for long voyages, which is authorized to carry not more than 12 passengers, excluding the crew, and the foreign yacht is a vessel used for sports and entertainment of a foreign nationality, which is considered as such according to the regulations of the country under the flag of which it sails. The Regulation on Boats and Yachts (OG 27/05, 57/06, 80/07, 3/08, $18 / 09,56 / 10,97 / 12,137 / 13,18 / 16,72 / 17)$ lists also the types of boats and yachts. According to Art. 2 of the Regulation on Types and Categories of Vessels used in Nautical Tourism (OG 69/08, $83 / 09,49 / 15)$, nautical tourism vessels are as follows: a ship, a boat or a yacht which are furnished and equipped for providing nautical tourism services.

\section{NEW REGULATIONS INTRODUCED BY THE DRAFT BILL ON THE AMENDMENTS TO THE MARITIME CODE / Novine u Nacrtu prijedloga Zakona o izmjenama i dopunama Pomorskog zakonika}

In the Draft Act on the Amendments to the Maritime Code (hereinafter referred to as: Draft Bill), the meaning of the terms ship, boat and yacht has been substantially amended (Art.3). Ship, excluding the warship, is a vessel intended for maritime navigation, the hull length of which is over $15 \mathrm{~m}$, or it is authorized to carry more than 12 passengers. Ships can be of different types, such as a passenger ship, a cargo ship, a technical vessel, a fishing vessel, a public vessel and a scientific research vessel. Boat is a vessel intended for maritime navigation authorized to carry up to 12 passengers, the hull length of which is over 2.5 $\mathrm{m}$, less or equal to $15 \mathrm{~m}$, or of the total propulsion power over $5 \mathrm{~kW}$ (the term boat does not include the following: - vessels belonging to another naval facility which is used for the purpose of collecting, rescuing or performing of work - vessels intended exclusively for competition - canoes, kayaks, gondolas and pedalos - sailboards and surfboards). Yacht is a vessel intended for sports and entertainment, regardless of whether it is used for private or business purposes, the hull length of which is over $15 \mathrm{~m}$, and which is intended for longer voyages, and in addition to the crew it is authorized to carry up to 12 passengers. Foreign yacht is a vessel of a foreign nationality intended for sports and entertainment, and considered as such by the laws and regulations of the country under the flag of which it sails.

The brand new terms are passenger yacht and yacht user. Large passenger yacht is a yacht the hull length of which is $24 \mathrm{~m}$ or more, and which is authorized to carry more than 12 passengers, but not more than 36. Yacht user, i.e. boat user is a natural or legal person that holds the yacht, i.e. boat in possession as its owner or based on the charter or lease agreement, presuming, unless the contrary is proved, that the yacht, i.e. boat user is the person listed as the owner in the Register of Vessels. The provisions of the Shipping Agent Code (Part 6 of the MC) apply to the yacht and boat user in a specific way. One of the rights of the shipping agent is the right to limit one's liability. 
Table 1 Vessels in nautical tourism

Tablica 1. Plovni objekti u nautičkom turizmu

\begin{tabular}{|c|c|c|c|c|c|c|c|}
\hline & \multicolumn{3}{|c|}{$\mathrm{MC} / \mathrm{PZ}$} & \multicolumn{4}{|c|}{ Draft Bill/Nacrt } \\
\hline & boat/brodica & yacht/jahta & ship/brod & boat /brodica & yacht/jahta & $\begin{array}{l}\text { large passenger } \\
\text { yacht / velika } \\
\text { putnička jahta }\end{array}$ & ship/brod \\
\hline $\begin{array}{l}\text { Length / duljina } \\
\text { u metrima }\end{array}$ & $2,5-12$ & $\begin{array}{l}\text { over / veća } \\
\text { od } 12\end{array}$ & $\begin{array}{l}\text { over / veća } \\
\quad \text { od } 12\end{array}$ & $2,5-15$ & $\begin{array}{l}\text { over / veća } \\
\text { od15 }\end{array}$ & 24 over / 24 i veći & $\begin{array}{l}\text { over / veća } \\
\text { od } 15\end{array}$ \\
\hline Power / porivna snaga & $\begin{array}{l}\text { over / veća od } \\
5 \mathrm{~kW}\end{array}$ & & & $\begin{array}{l}\text { over / veća od } \\
5 \mathrm{~kW}\end{array}$ & & & \\
\hline Passenger / broj putnika & & $\max .12$ & $\begin{array}{l}\text { over / više } \\
\quad \text { od } 12\end{array}$ & $\max .12$ & $\begin{array}{l}\text { up to / do } \\
12\end{array}$ & $12-36$ & $\begin{array}{l}\text { more than / } \\
\text { više od } 12\end{array}$ \\
\hline $\begin{array}{l}\text { Gross tonnage / bruto } \\
\text { tonaža }\end{array}$ & & & $\begin{array}{l}\text { over / veća } \\
\quad \text { od } 15\end{array}$ & & & & \\
\hline
\end{tabular}

Source: Authors

\subsection{Charter contract / Ugovor o najmu jahte i brodice}

In addition to the existing lease agreement, the legislator has introduced the yacht and boat contract into the MC intended for navigation for the purpose of recreation.2 The yacht or boat can be leased with or without the crew. The goal is to increase legal certainty through the model of the agreement on the regulation of mutual rights and obligations of this legal transaction.

The ship lease agreement and the yacht and boat charter agreement are quite similar with respect to the fundamental constituents of the agreements. With the ship lease agreement, Lessor shall give the ship to the Lessee for use (Author's comment), with the payment of rental, for the purpose of maritime activity. The charter contract is the agreement in which the Lessor agrees to concede the yacht or boat to the Lessee for use (Author's comment), and the Lessee agrees to pay to the Lessor the specific rent. Therefore, in both leasing and chartering, the vessels (i.e. ships, yachts and boats) are conceded for use for a fee (lease, i.e. rent).

There are also some differences between these two types of contracts: first, the ship lease agreement must be concluded in writing, so the one that was not concluded in such form has no legal effect (Art. 659 of the MC), while according to the Draft Bill, there is no such severe provision for yacht and boat charter contracts; secondly: the Lessee can sub-lease the vessel exclusively based on the written consent of the Lessor (Art.672 of the MC), while the Lessee can sub-lease the yacht or boat exclusively based on the consent of the Lessor (the oral consent is sufficient).

We believe that the afore-stated differencies represent the main shortcomings of the Draft Bill due to potential abuse of rights, with the abuse of rights meaning the achieving of the obligatory relations rights contrary to the purpose for which it has been established by the regulations.

The basic constituents of the yacht and boat charter contract are the following:

vessel which is the subject matter of the charter contract,

duration of the charter contract,

charter fee.

Yacht and boat charter contracts are often accompanied by insurance (Ćorić, 2018). Yacht and boat insurance is a specific

${ }^{2}$ Regulations on the requirements for vessel charter services with or withou the crew and for providing passenger onboard accommodation services (OG 42/17) - hereinafter referred to as: Regulations on Charter Activities) regulate the conditions and means of providing yacht and boat rental services with or without the crew (charter) including the providing of passenger onboard accommodation services in the internal waters and the territorial sea of the Republic of Croatia. form of vessel insurance. It includes the following: a) the hull and machinery insurance (all-risk insurance), and b) vessel owner and user liability insurance, and liability insurance for various persons participating in the commercial use of yachts and vessels in different positions. Pavić (2012) emphasizes that the yacht and boat all-risk insurance is voluntary, and the liability insurance in its limited scope is compulsory. The Compulsory Liability Insurance Law (OG 151/05, 36/09, 75/09, 76/13, 152/14) provides for mandatory liability insurance for the (fishing) boat and yacht owners for damage caused to third parties, with the insurance covering personal injuries (Art. 41).

\subsection{Contract of nautical berth / Ugovor o nautičkom vezu}

The Regulations on the conditions and modalities of maintaining order at the ports and in other parts of the internal waters and the territorial sea of the Republic of Croatia (OG 90/05, 10/08, $155 / 08,80 / 12,7 / 17)$ do not specify any obligations of the port authorities, such as port administration and concession holders, to conclude the contracts on nautical berth with port users.

According to the Draft Bill, the contract of nautical berth obliges the onshore or offshore berthing service provider to concede (Author's comment) the berth to the berth user for the accommodation of a specific yacht or boat, including the persons onboard, and the berth user is required to pay the berthing dues to the berthing service provider. The contract of nautical berth can be either a commercial or a consumer contract. Its essential constituents are as follows:

berth at the pier,

vessel which is the subject matter of the berth contract,

duration of the berth contract,

berthing dues

Still though, there are three issues that are open for debate, such as: a) types of services the berthing service provider is required to provide, b) the maritime lien, and c) the nautical berth inheritance right.

\subsubsection{Types of services berth provider is obliged to deliver / Vrste usluga na koje se obvezuje pružatelj usluga veza}

The core obligations of the mooring provider are as follows: a) to concede a safe berth to the berth user, and b) to maintain the berth exercising all due skill in order to keep it functional and safe. The first type of service is very clear, but the second one needs further clarification.

The compulsory relation participant is required to act with utmost care, professionally and according to the customs 
in fulfilling his or her professional obligations (according to the principles of good governance) (Art.10, par. 2 of the Civil Obligations Act, OG 35/05, 41/08, 125/11, 78/15 - hereinafter referred to as: $(O A)$. We believe that the increased degree of care required from the mooring service provider as part of his professional activity has exceeded due diligence and has entered the greater degree of extraordinary care). 3 This is why the provision of the agreement on the limitation or exclusion of liability for material deficiencies of the berth is null and void if the deficiency was known to the mooring service provider, and he did not inform the berth user about it, and when the berth provider imposed this contract term using his monopoly position, and if this concerns a consumer agreement. All the other types of services of the mooring service provider are optional. Yacht or boat supervision, if expressly agreed, means to perform the usual external inspection in order to check the condition of the yacht or boat and its equipment, and it may include the checking of the condition of the yacht or boat interior. According to Pavić (2012), if the berth provider has assumed the obligation of yacht and boat under the contract, he or she may have an interest in obtaining his or her liability insurance. Liability means the liability of the insured person as the nautical port entrerpreneur for the loss or damage to the yacht. The berth contract may also stipulate that during the mooring the berth user will use the services of the workers of the vessel mooring service provider. According to the decision of the High Commercial Court of the Republic of Croatia nr. Pž904/09 dated July 30, 2009: “Dock workers whose services the shipowner usually uses when mooring are not third parties, but are part of the occupational hazard the shipowner is responsible for. In case a crew member is injured during the mooring, the omission of the shipmaster in coordinating the participants of such operation represents the basis for the shipowner's liability for the claim." ${ }^{4}$

\subsubsection{Right of retention / Pravo zadržanja}

The right of retention is an institute from the Civil Obligations Act (COA) (Art.72-75). The outstanding claim creditor who has a specific debtor's property in his possession has the right to retain it until his claim is settled. If the debtor becomes insolvent, the creditor has the right of retention although his claim has not been settled. The creditor retaining the debtor's property based on the right of retention has the right to recover his expenses from its value in the same way as a lienor. This is why the right of retention plays an important role in the maritime law. It serves as a means of protection of the creditor's interest in situations where the specific creditor does not have a legitimate lien (maritime lien) over his claim (Mintas-Hodak, 1989). According to Article 437 of the MC, the ship repair specialist who has the ship under construction or undergoing repair in the ship yard, has the right to retain the ship until his claims are settled. Tasić (2014) claims that the moment the ship repair specialist dispossesses himself of the factual property, even though his claims have not been settled based on the provisions of the ship repair contract, the ship repair specialist does not have the creditor status referred to in Art. 437 of the MC, neither does he

${ }^{3}$ Legislature does not provide such a high degree of care for the berth user. He is required to use the berth in accordance with the contract and its purpose as a good manager, i.e. good host (Art. 10, par.1 of the COA).

${ }^{4}$ According to Art. 2 of the Regulations on Charter Activities, the marine vesse master is a person operating the vessel responsible for its safety and lawful use. have a guaranteed order with respect to the mortgage lender as referred to in Art. 912 of the MC.

Therefore, the berth provider also has the right to retain the yacht or boat on all assets, at the agreed berth or in a way as to transfer it to another safe onshore or offshore berth until the full settlement of the following: a) outstanding berthing fees, b) other claims defined in the berth contract, and c) claims incurred in relation to the stay and stopping of boats at the berth following the expiration, termination, suspension or cancellation of the berth contract.

\subsubsection{Right to nautical berth inheritance / Pravo nasljeđivanja veza}

The berth user is required to use the berth in compliance with the provisions of the contract and its purpose as a good manager, i.e. a good host (supra note). The berth user is not allowed to concede the berth to third parties for use, since the mooring service provider can terminate the contract in that case, and is also entitled to compensation. The Draft Bill stipulates that the berth contract shall terminate if the berth collapses, and there is no possibility to transfer the yacht or boat to another adequate berth. The nautical berth contract shall also terminate if the yacht or boat for which the contract is stipulated gets destroyed.

We believe that reasonable grounds for terminating the nautical berth contract are also the following:

- removing the commercial user of the berth from the specific registers (records),

changing of the ownership right to the yacht or boat, because the berth service provider concludes the nautical berth contract with the specific legal entity (vendor) or the specific natural person (user).

The Draft Bill does not regulate the right to nautical berth inheritance in the event of the user's death, either, which it should be doing modeled on the right to retention. Based on the decision on inheritance, the berth service provider will eventually conclude a new nautical berth contract with the successor(s).

\subsection{Problems related to the coordination and harmonization of regulations in the Croatian State Administration System / Problem koordinacije i harmonizacije propisa u sustavu hrvatske državne uprave} Ministers, state secretaries at central state offices and heads of state administration organizations adopt regulations, orders and directives on law and regulation enforcement when they are legally authorized to do so, within their respective powers (Art.18 of the Law on State Administration, OG 150/11, 12/13, $93 / 16,104 / 16)$. The problem arises when there is no cooperation between the ministries, raising the issue of regulation harmonization.

Nautical tourism is within the remit of the Ministry of Maritime Affairs on one hand and the Ministry of Tourism on the other one. The analysis of the legal framework has confirmed the following:

1. Regulation on Classification and Categorization of Ports for Nautical Tourism was supposed to be issued by the Minister of Maritime Affairs instead of the Minister of Tourism, because the Maritime Domain and Seaports Act regulates the issue of classification of all the seaports. The Minister 
of Maritime Affairs has issued the Regulation of Boats and Yachts, not the Minister of Tourism.

2. Regulation of Charter Activities stipulates that the vessel is a seacraft defined by the Maritime Code as a boat or yacht, used for charter activities. It follows that the rental of the ship as a seacraft is not possible, although the Law on Providing Services in Tourism (OG 130/17) also classifies the ship as a seacraft (Art. 85). And according to Art. 2 of the Regulation on Types and Categories of Vessels Used in Nautical Tourism, nautical tourism vessels are a ship, a boat and yacht.

\section{ACT ON THE PROVISION OF TOURISM SERVICES / Zakon o pružanju usluga u turizmu}

The part of the legal framework that is supposed to contribute to the development of nautical tourism as an industry is the afore-mentioned Act on the Provision of Tourism Services which has been in force since January 1, 2018. The said Act stipulates that nautical tourism presupposes navigation and staying of tourists (as yachtsman or passenger) onboard vessels (such as a yacht, boat or ship) used for personal or business purposes, as well as the staying at nautical tourism ports and the part of nautical ports open to public traffic for the purpose of vacation, recreation and cruising (Art.84). The Article 85 of this Act provides for the typology of tourism services within the nautical tourism domain, such as the following: 1. berth utilization services, reception and accommodation of vessels with or without tourists or yachtsmen onboard, 2. charter services - vessel utilization with or without the crew, with or without accommodation and/or food services, for the purpose of vacation, recreation, and cruising of yachtsmen, 3 . organizing package tours or trips onboard the nautical tourism vessels, 4. reception, conservation, and maintenance of vessels at the berth in the sea and at the dry dock, 5. furnishing and preparation of vessels, and 6. other types of tourist-oriented services. Finally, Art.86 enumerates the locations where the nautical tourism services are provided, such as: 1 ) the nautical tourism seaports (marinas and other berthing and vessel accommodation facilities - nautical anchorage, dry dock, and vessel storage facility, 2) in the nautical part of the seaports open to public transport, and 3) onboard nautical tourism vessels.

\section{COMPARATIVE LAWS / Usporedna prava}

An overview of the legal regulations related to the chartering of the yachts and boats used for entertainment, as well as the contract on the nautical berths in Italy, Spain and France, i.e. Mediterranean countries where nautical tourism represents a significant business activity.

\subsection{Italy / Italija}

Nautical tourism in Italy is regulated by the Recreational Navigation Act (ita. Codice della nautica da diporto, Gazzetta Ufficiale, Decreto Legislativo, n.171/05, n. 229/17 - hereinafter refereed to as: Code). The Code contains the provisions on the lease (locazione) and charter (noleggio) of vessels for recreation (Art. $42-46$, and 47-49). For both types of contracts to be valid they require a written form under the threat of nullity, and the contract must be kept onboard the vessel in its original form or its certified copy. Therefore, the charter contract states the following: /l contratto di noleggio o di subnoleggio delle imbarcazioni e delle navi da diporto è redatto per iscritto a pena di nullità e deve essere tenuto a bordo in originale o copia conferma.

With the contract the Lessor makes the vessel for entertainment available to the Lessee for the purpose of recreation at sea and inland waters of his choice, in line with the contractual provisions, for a specific time period and a fee. The charter contract can be sub-chartered, and the lease contract can be sub-leased.

According to Orro (2018), the charter agreement can be stipulated only for a specific time period (time charter). He goes on to explain why these provisions do not apply to the lease agreement: 1.) the chartered vessel remains the property of the Lessor, and 2.) the vessel crew remains under the authority of the Lessor. Pasino (2018) considers that the most significant change made to the Code with respect to the Italian Maritime Code is that it expressly provides the commercial use of vessels for entertainment for the first time.

The Code does not set out the provisions on the berth contract, nor does it define the term and content of the berth contract (contratto di ormeggio) (Pijaca, 2018).

According to the annual report entitled /I Diporto Nautico in Italia Anno 2016, there are three different pleasure craft categories, such as: a) up to $10 \mathrm{~m}$ long, and unspecified crafts, b) from 10.01 up to $24 \mathrm{~m}$ long, and c) over $24 \mathrm{~m}$ long.

\subsection{Spain / Španjolska}

The journal entitled "Naše more" issue nr.3/2107 we published the article related to sports ports in Italy, Spain and France. We emphasized that in Spain the granting of the concession of the seaports for sports and recreation purpose is the responsibility of the self-governing units (esp. Comunidades Autonomas) or regions. Art. 97 of the Law on the Seaports of Catalonia (esp. Ley 5/1998, de 17 de abril de Puertos de Cataluna) enlists the types of berths. The berths can be intended for private use can be connected or non-connected with the neighboring spot, and public use berths. In case there are changes in concession holders on the neighboring spot, the berth user has the preference right. The berth contract cannot be stipulated for the period longer than 30 years, i.e. for longer than the duration of the concession.

The Law on the Seaports of Catalonia has not regulated the form and content of the berth contract between the concession holder and the berth user, so their business relations are regulated by their own free will through (esp. acuerdo de amarre). This Law has not regulated the issue of the charter of vessels for sports and recreation purpose, either.

This is done by the Maritime Navigation Act (esp. Ley 14/2104 de 24 de Julio de Navigacion Maritima - hereinafter referred to as: LNM) in Articles 307 - 313, section V, chapter IV. With the vessel charter contract the Lessor/Owner gives the vessel at the disposal of the Lessee for a specific fee (charter fee) for the specific time period, and exclusively for sports or recreation purpose (esp. Por el contrato de arrendamiento náutico el arrendador cede o pone a disposición del arrendatario, a cambio de precio, un buque o embarcación por un período de tiempo y con una finalidad exclusivamente deportiva o recreativa) (Art.307 of the LNM). Charter contract can be stipulated with the provision including or excluding the crew. The contract on the vessel charter with the crew must be regulated in line with 
section V, pursuant to the provisions of Art 210 of the LNM, and the contract that the parties stipulated and arranged. In the contract on the vessel charter without the crew the provisions set out in the section V apply, as well as the specific provisions of the chapter IV, as well as the agreement between the parties.

The vessel charter contract must be compiled in the written form (Art.189 of the LNM), and it is required that it be entered into the Movable Property Register (esp. Registro de Bienes Muebles) (Art.190 of the LNM) for the purpose of private security. The provisions of Art.307 -313 of the LNM are obligatory and cannot be modified.

The liability insurance is covered by the compulsory insurance company certificate. Liability for damage to third parties is ensured, as well as liability for travelers, including the crew. The vessel cannot carry more than 12 persons, in addition to the crew.

Pejoves (2018) explains that the vessel lease agreement and the vessel charter agreement (without the crew), represent the type of contracts where the vessel owner grants the vessel to the Lessee or the Charterer for use in exchange for compensation (fee). The legal nature of both types of the contracts is a consensual contract (lat. Locatio conductio rei).

\subsection{France / Francuska}

Nautical tourism is of vital significance in the Republic of France. Sailing for pleasure is popular among over 4 million of registered recreational sailors, and there are even more than 9 million of occasional yachtsmen. Nautical industry includes also more than 400 marinas with 252.000 berths and 40 solid facilities with 11.248 berths, so in this industry France represents the leading country in the Mediterranean, and worldwide (Cluster Maritime Francias, 2018).

According to Guerlet (2013), the fundamental regulation related to the issue of recreational ports is the Maritime Ports Code (fr. Code des ports maritimes, partie réglementaire, livre III, titre IV, chap 2 relatif au chargement et au déchargement des navires vraquiers, art R.342-1 à R.342-7, créés par décret $n^{\circ} 2009$ 876 du 17 juillet 2009, art 5, version consolidée du 9 mai 2011hereinafter referred to as: (PM). A part of the provisions of this Act has been transferred onto the Law on Transportation (Code des transports).

Article R. 631-4 of the CPM stipulates that the concession holder can sign a berth lease contract (fr. La location) with the interested party for the period of 1 year with the right of the berth user to renew the contract upon its expiration. In addition to the term berth rental, the CPM also defines the term "lease" in relation to the lease of a part of the maritime domain (fr. L'amodation) which is owned by the Republic of France, of course. This is the specific right granting exclusive rights to the use of the berth to individuals and corporations (fr. Droit de jouissance) through the purchase of marina concession holder's stocks. In this way, the recreational port becomes the so-called "Port Prive" (Heilikman, 2015).

Upon the inspection of the available forms of berth rental on the internet, as well as the adequate legal literature, and the provisions of the CPM, we can conclude that there is no legal obligation to conclude a berth rental contract in the prescribed form and content.

On the other hand, the rental of pleasure yachts and recreational seacrafts is often accompanied by the charter contract in the written form (fr. Contrat de Location d'un bateau de plaisance) with the mutual rights and obligations of Lessor and Lessee set out. The mandatory constituent of the contract is also the vessel and liability insurance.

Pleasure yachts and recreational vessels are pleasure seacrafts used for personal, family and sports purposes. They include the following: motor yachts, sailboats, luxury yachts (over $24 \mathrm{~m}$ ), super yachts (over $30 \mathrm{~m}$ ), and mega yachts (over $50 \mathrm{~m}$ ). None of the said yachts are authorized to carry more than 12 persons. The common feature of pleasure yachts and recreational seacrafts is their purpose: namely, they are used for sports and recreation, and therefore profit is completely excluded.

\section{CONCLUSION / Zaključak}

Nautical tourism is an industry which has been rapidly developing in the past thirty years in the Republic of Croatia. It is located mostly in the marinas which, as well as other nautical seaports, by definition being categorized as maritime domain. Each use of maritime domain must be based on the synergy of different interests, such as economic, public and the maritime domain protection ones. Here the ecology has a particular relevance since tourism, and nautical tourism in particular, is predominantly based on natural resources without which its existence would not be possible (Luković, Gržetić, 2007). The constitutional rule is that maritime domain enjoys a special State protection (Stanković, 2016). This is why the interest of the maritime domain protection must always come first.

In 2017, revenues obtained from berth rental in the Republic of Croatia accounted for over $70 \%$ of all the revenue generated, with as much as $97 \%$ being generated by yachts (sailboats and motor yachts) according to the vessel type.

The survey has also included comparative rights and practice. In Italy and Spain, the vessel rental agreements must be compiled exclusively in the written form by force of law, and for the purpose of legal certainty. In Croatia, there are no such strict legal provisions. On the other hand, the Italian, Spanish, and French legislators have not regulated berth contracts, including nautical berth contracts, through legal acts, but have allowed the contractual parties to define its shape and content (the so-called autonomy of the parties). The Draft Bill to the Act on Amendments to the Maritime Code provides for the nautical berth contract containing as many as fifteen (15) articles. The provision on the right of the mooring service provider (at marinas) to retain (retention) the yacht or boat until the full settlement of the outstanding berthing dues and other claims set out in the berth contract, as well as the claims arising in connection to the stay and stopping of the vessels at the nautical berth, is logical and makes sense.

Thus, it can be concluded that regulation of the contractual relationship, as set up in The Draft Bill to the Act on Amendments to the Maritime Code, provides a nautical berth contract which derogates from a fundamental contract principle and that is a "will between the parties". Excessive legal interference with nautical tourism and its sustainable development, along with the absence of an economic goal, leads to the arbitrariness of a legislator who does not have sufficient knowledge of the factors of nautical tourism and its development. So, the research hypothesis is rejected. It is therefore concluded that inadequacy of Croatian legislation should be compensated by applying 
business customs and practices with prescribed enforcement, undoubtedly with higher degree of understanding of the nautical tourism industry in Croatia.

\section{REFERENCES / Literatura}

[1] Bolanča, D. (2003) Pravni status morskih luka kao pomorskog dobra u Republici Hrvatskoj. Pravni fakultet Sveučilišta u Splitu. Split

[2] Ćorić, D. (2018) Primjena odredbi Pomorskog zakonika o izvanugovornoj odgovornosti vlasnika broda i brodara na jahte i brodice. PPP Vol. 57 (2018) 172, pp. 131-147

[3] Grabovac, I. (1993) Pomorsko pravo. Split

[4] Gueret, G. (2013) Le gestion des ports par une entite publigue: aspects europeens et environnementaux. Doktorska disertacija. Dostupno na: https://tel.archives-ouvertes.fr/tel-00983306/document (1.2.2018.)

[5] Heilikman, J. (2015) Juridique - ports de plaisance et plaisanciers: police portuaire, environnement, location, dmodition et fiscalite. ACTU NAUTIQUE. Dostupno na: http://www.actunautique.com/2015/03/juridique-portsde-plaisance-et-plaisanciers-police-portuaire-environnement-locationamodiation-et-fiscalite.html (15.1.2018.)

[6] Luković, T. Gržetić, Z. (2007) Nautičko turističko tržište u teoriji i praksi Hrvatske i europskog dijela Mediterana. Split

[7] Mintas - Hodak, Lj. (1989) Retencija u pomorskom pravu. UPP. Vol.31, (1), pp.97-124

[8] Orru, E. (2018) Contracts used for charter or lease of pleasure vessels in pleasure navigation: an Italian perspective. PPP.Vol. 57 (2018), 172, pp.. 75-95

[9] Passino, A. (2018) The reform of the Italian Yachting code. PPP. Vol. 57 (2018), 172, pp.47-56

[10] Pavić, D. (2012) Pomorsko osiguranje Pravo i praksa. Književni krug Split

[11] Pejoves, A. (2018) El contrato de Fletamento o Casco Desnudo (Bareboat Charter). MundoMaritimo. Dostupno na: https://www.mundomaritimo. $\mathrm{cl} /$ noticias/el-contrato-de-fletamento-a-casco-desnudo-bareboat-charter (1.2.2018.)

[12] Pijaca, M. (2018) Pravni odnosi između marine i charter kompanije u svezi s ugovorom o vezu - prikaz hrvatske i komparativne poslovne prakse. PPP. Vol. 57 (2018), 172, pp.253-284

[13] Stanković, G. (2016) Bankabilnost kao preduvjet razvitka pomorskog dobra. Specijalizirani portal Pomorsko dobro. Dostupno na: http://www. pomorskodobro.com/misljenje-gordan-stankovic.html (15.1.2018.)

[14] Tasić, Z. (2014) Što je prije: retencija broda ili pomorska hipoteka? Znanstveni skup Pomorsko pravo i pravo mora:jadranske zemlje u eruropskim okvirima. Zagreb. p.16.
[15] Vuković, A. (2017) Zakon o sportu u funkciji razvoja luka nautičkog turizma Hrvatske i Mediterana (I. dio). Naše more. Vol.64 No.3.pp 92-96. https://doi. org/10.17818/NM/2017/3.13

[16] Vuković, A. (2018) Sports Actas a Function of Nautical Tourism Development in Croatia and in the Mediterranean, part II. Naše more. Vol.65. No.2. pp. pp.103-112. https://doi.org/10.17818/NM/2018/2.6

[17] II Diporto Nautica in Italia Anno 2016. (2016). Dostupno na: http://www.mit. gov.it/diporto-nautico-italia-2016 (15.2.2018)

[18] Cluster Maritime Francias 2016-2017 (2018). Dostupno na: http://www. cluster-maritime.fr (20.2.2018.)

\section{Regulations / Propisi}

1. Zakon o pomorskom i vodnom dobru, lukama i pristaništima (N.N. 19/74, 24/74, 39/74, 39/75, 17/77, 18/81).

2. Pomorski zakonik (N.N. 17/94).

3. Zakon o izmjenama i dopunama Pomorskog zakonika (N.N.74/94).

4. Zakon o morskim lukama (N.N. 158/95).

5. Zakon o pomorskom dobru i morskim lukama (N.N. 158/03, 100/04, 141/06, 38/09, 123/11, 56/16).

6. Zakon o pomorskoj i unutrašnjoj plovidbi (Službeni list SFRJ, 22/77).

7. Pomorski zakonik (N.N. 181/04, 76/07, 146/08, 61/11, 56/13, 26/15.

8. Zakona o obveznim odnosima (N.N. 35/05, 41/08, 125/11, 78/15).

9. Zakon o sustavu državne uprave (N.N. 150/11, 12/13, 93/16, 104/16).

10. Zakon o pružanju usluga u turizmu (N.N. 130/17).

11. Zakon o obveznim osiguranjima od odgovornosti (N.N. 151/05, 36/09, 75/09, 76/13, 152/14)

12. Codice della nautica da diporto (Gazzete Ufficiale, Decreto Legislativo n. 171, n.229/17).

13. Ley $5 / 1998$, de 17 de abril, de Puertos de Cataluna.

14. Ley $14 / 2104$ de 24 de Julio de Navigacion Maritima.

15. Pravilnik o brodicama i jahtama (N.N. 27/05, 57/06, 80/07, 3/08, 18/09, 56/10, 97/12, 137/13, 18/16, 72/17).

16. Pravilnik o razvrstavanju i kategorizaciji luka nautičkog turizma (N.N. 72/08).

17. Pravilnik o vrstama i kategorijama plovnih objekata nautičkog turizma (N.N. 69/08, 83/09, 49/15).

18. Pravilnik o uvjetima za obavljanje djelatnosti iznajmljivanja plovila sa ili bez posade i pružanje usluge smještaja gostiju na plovilu (N.N.42/17).

19. Pravilnik o uvjetima i načinu održavanja reda u lukama i na ostalim dijelovima unutarnjih morskih voda i teritorijalnog mora Republike Hrvatske (N.N. 90/05, $10 / 08,155 / 08,80 / 12,7 / 17)$. 